\title{
Organization and planning for the creation of the HIV testing and counselling center
}

\author{
Organização e planejamento para a criação do centro de testagem e aconselhamento para HIV \\ Organización y planeamiento para la creación del centro de pruebas y guía para VIH
}

\section{Hercília Regina do Amaral Montenegro' ORCID: 0000-0002-6007-949X}

Pacita Geovana Gama de Sousa Aperibense" ORCID: 0000-0002-3176-2134

Tania Cristina Franco Santos' ORCID: 0000-0003-2325-4532

Gizele da Conceição Soares Martins" ORCID: 0000-0002-3868-7173

Antonio José de Almeida Filho' ORCID: 0000-0002-2547-9906

'Universidade Federal do Rio de Janeiro. Rio de Janeiro, Rio de Janeiro, Brazil.

"Universidade Federal do Rio de Janeiro. Macaé, Rio de Janeiro, Brazil.

How to cite this article: Montenegro HRA, Aperibense PGGS, Santos TCF, Martins GCS, Almeida Filho AJ. Organization and planning for the creation of the HIV testing and counselling center. Rev Bras Enferm. 2021;74(1):e20200615. doi: http://dx.doi.org/10.1590/0034-7167-2020-0615

Corresponding author: Antonio José de Almeida Filho E-mail:ajafilhos@eean.ufrj.br

EDITOR IN CHIEF: Dulce Barbosa ASSOCIATE EDITOR: Fátima Helena Espírito Santo

Submission: 06-05-2020

Approval: 09-13-2020

\section{ABSTRACT}

Objectives: To analyze the process of creating the HIV Testing and Counselling Center in the municipality of Nova Iguaçu, in the state of Rio de Janeiro. Methods: qualitative research, with a historical approach. The direct sources consisted of written documents and 11 oral testimonies. Results: in order to create this Testing and Counselling Center, investment was made in the implementation of a Municipal Management Unit for the STD/AIDS Program; in the elaboration of the Project for the Creation of the Testing and Counselling Center; in the process of attracting, selecting and training human resources; and choosing the right place for its operation. Final Considerations: the nurse who coordinated this investment had the support of the authorities of that municipality and had an authorized speech on HIV/AIDS in the municipality of Nova Iguaçu; planned each stage of this service and used effective strategies to create the Testing and Counselling Center.

Descriptors: HIV Antibodies; History of Nursing; Health Policy; Public Health Nursing; Health Management.

\section{RESUMO}

Objetivos: analisar o processo de criação do Centro de Testagem e Aconselhamento para HIV no município de Nova Iguaçu, no estado do Rio de Janeiro. Métodos: pesquisa qualitativa, de abordagem histórica. As fontes diretas constituíram-se de documentos escritos e 11 depoimentos orais. Resultados: para a criação desse Centro de Testagem e Aconselhamento, investiu-se na implementação de uma Unidade de Gerenciamento Municipal do Programa DST/aids; na elaboração do Projeto de Criação do Centro de Testagem e Aconselhamento; no processo de captação, seleção e capacitação de recursos humanos; e na escolha do local adequado para seu funcionamento. Considerações Finais: o enfermeiro que coordenou esse investimento contou com o apoio das autoridades daquele município e tinha discurso autorizado sobre HIV/Aids no município de Nova Iguaçu; planejou cada etapa desse serviço e se utilizou de estratégias eficazes para a criação do Centro de Testagem e Aconselhamento. Descritores: Anticorpos Anti-HIV; História da Enfermagem; Política de Saúde; Enfermagem em Saúde Pública; Gestão em Saúde.

\section{RESUMEN}

Objetivos: analizar el proceso de creación del Centro de Prueba y Guía para VIH en el municipio de Nova Iguaçu, en Rio de Janeiro. Métodos: investigación cualitativa, de abordaje histórico. Las fuentes directas constituyeron de documentos escritos y 11 deposiciones orales. Resultados: para la creación de eso Centro de Prueba y Guía, se embistió en la implementación de una Unidad de Gestión Municipal del Programa ETS/Sida; en la elaboración del Proyecto de Creación del Centro de Prueba y Guía; en el proceso de captación, selección y capacitación de recursos humanos; $y$ en la selección del local adecuado para su funcionamiento. Consideraciones Finales: el enfermero que coordinó esa inversión contó con el apoyo de las autoridades de aquello municipio y tenía discurso autorizado sobre coordinó en el municipio de Nova Iguaçu; planeó cada etapa de eso servicio y utilizó estrategias eficaces para la creación del Centro de Prueba y Guía.

Descriptores: Anticuerpos Anti VIH; Historia de la Enfermería; Política de Salud; Enfermería en Salud Pública; Gestión en Salud. 


\section{INTRODUCTION}

The Testing and Counselling Center (TCC) was considered a health service for the purpose of prevention and diagnosis of the Human Immunodeficiency Virus (HIV). These Centers were implemented, nationwide, from 1992, through the Ministry of Health's National STD/AIDS Control Program. Initially called Center for Orientation and Serological Support (COAS), it received the new name in 1996.

This initiative by the Ministry of Health was due to the need to contain the advance of the AIDS epidemic, which, since the 1980s, has entered the health scenario in the world and in Brazil. At first, it was considered a pathology unknown to health professionals and scientists. In 1981, the American press, through the Official Bulletin of the Center of Disease Control (CDC), announced the new disease, linking it to a specific group of society, men who had sex with other men, which made people see the situation through a charged and blurred prism of moral conceptions. The epidemiological relevance of the disease was based on the high mortality rate ${ }^{(1-2)}$. It did not take long for new cases to be identified in other countries such as France, Belgium, Switzerland, Denmark, Germany and Spain ${ }^{(3)}$.

With regards to Brazil, the first case was diagnosed in 1982, in the state of São Paulo. From then on, new cases were identified in the different states of the federation. According to the Ministry of Health, in 1990 there were already 600 thousand cases of the disease in the country; and approximately $70 \%$ were people in the productive phase aged 20 to 39 years. It is worth mentioning that the epidemiological magnitude of the disease was related to the high number of cases and high mortality rates. As for the mortality rate, the number of deaths per 100 thousand inhabitants in the Brazilian regions was distributed as follows: 20 in the Southeast; 5.5 in the Midwest; 3.4 in the North; 3.2 in the South; and 3 in the Northeast region ${ }^{(4-5)}$.

In addition, among the Brazilian regions, the Southeast Region had the highest number of AIDS cases, with about 170 thousand notifications, which represented $67 \%$ of the total cases in the period from 1982 to $2001^{(6)}$. Regarding the state of Rio de Janeiro, about 35 thousand cases were reported, and $90 \%$ of these were concentrated in Metropolitan Region I, consisting of 11 municipalities: Nova Iguaçu, Japeri, Queimados, Magé, Duque de Caxias, Belford Roxo, Nilópolis, São João de Meriti, Rio de Janeiro, Seropédica and Itaguaí. The municipality of Nova Iguaçu (NI) had the second highest number of notifications of the disease, with 2,070 cases, corresponding to $5.8 \%$ of the total notifications in the state of Rio de Janeiro ${ }^{(7)}$. Thus, among the municipalities in the state of Rio de Janeiro, Nova Iguaçu had the highest AIDS rates, in terms of both incidence and mortality, with 20.9 deaths per 100 thousand inhabitants, exceeding the Brazilian and Southeast average, considered the region with the worst indicators for the disease ${ }^{(8)}$.

In this context of the fight against HIV/AIDS, the Coordinator of the National STD/AIDS Program, Lair Guerra de Macedo Rodrigues, highlighted the creation, at the national level, of Testing and Counselling Centers. It is worth mentioning that the implantation of this device occurred through International Cooperation, involving the World Bank, the Ministry of Health and the Health Departments of the states and municipalities. In order to guarantee actions in a systematic way, the Coordinator of the National STD/AIDS Program prepared a document entitled Norms of Organization and Functioning of the Serological Guidance and Support Centers, in 1993 $3^{(9-10)}$.

Thus, in 1994, actions were initiated for the creation and implementation of the Testing and Counselling Center in the municipality of Nova Iguaçu. In this municipality, such responsibility was left to the Municipal Management Unit (UGM) of the STD/AIDS Program, linked to the Department of Collective Health of the Municipal Health Secretariat of Nova Iguaçu. To this end, it required the technical manager of the UGM STD/AIDS to carry out an expanded plan with a view to selecting human resources, training these professionals and defining an appropriate place for the TCC to function.

This study aims to contribute to a better understanding of the HIV/AIDS epidemic and of the strategies for creating a specialized service of great social impact in the fight against the disease in Brazil and especially in the municipality of Nova Iguaçu.

To this end, the following guiding question was elaborated: How did the planning for the creation of the first Testing and Counselling Center in Baixada Fluminense (region of the state of Rio de Janeiro, Brazil) take place?

\section{OBJECTIVES}

To analyze the process of creating the HIV Testing and Counselling Center in the municipality of Nova Iguaçu, in the state of Rio de Janeiro.

\section{METHODS}

\section{Ethical aspects}

Ethical aspects were respected, according to the recommendations of Resolutions no. 466/12 and 510/16 of the National Health Council. For the interviews, all participants signed an Informed Consent Form. After their transcripts, they were presented to each participant for reading and validation. Access and consultation of written documents were authorized by the municipal authorities, after signing the consent form. The study was approved by the Research Ethics Committees of the Anna Nery School of Nursing/ Hospital Escola São Francisco de Assis (EEAN/HESFA).

\section{Study type}

It is a study of historical approach, from the perspective of the History of the Present Time, whose corpus was composed of direct written and oral historical sources, and indirect sources used to support the discussion of the results. COREQ guidelines were followed.

The time frame comprises the years 1994 and 1995, when the actions for the creation and implantation of this Testing and Counseling Center began.

\section{Methodological procedures}

\section{Study scenario}

The scenario is the Testing and Counselling Center, a reference unit for HIV/AIDS prevention and diagnosis actions in the municipality of Nova Iguaçu, state of Rio de Janeiro. 
It should be noted that the municipality of Nova Iguaçu is part of the region called Baixada Fluminense, consisting of 13 municipalities, whose geographical area represents $61 \%$ of the Metropolitan Region of the state of Rio de Janeiro. With a territorial area of 558 $\mathrm{km}^{2}$, Nova Iguaçu is considered the largest municipality in Baixa Fluminense and the second in the Metropolitan Region of the state of Rio de Janeiro. As for the population in the early 1990s, it was approximately 600 thousand inhabitants, considered as the second largest city in the Baixada Fluminense, the fourth most populous in the state and the $21^{\text {st }}$ in the country ${ }^{(11)}$.

\section{Historical sources}

The direct written historical sources consisted of Norms, Manuals of the Ministry of Health, Project for the Creation of the Nova Iguaçu Testing and Counselling Center, Nominal list of TCC team professionals, Official Gazette of Rio de Janeiro.

The direct oral sources consisted of interviews with 11 employees, among whom are nurses (2); psychologists (2); social workers (3); physician (1) nursing technician (2), and laboratory technician (1) in the following positions and functions: coordinator of the Municipal STD/AIDS Program, TCC technical officer, advisers, receptionist and collector, who participated in the creation process and TCC implementation. For the interviews, a semi-structured script was used with questions about the planning for the creation of the TCC, composed of the following contents: selection and training of professionals; definition of the location and its organization; challenges and strategies to overcome. The duration of the interviews ranged from 45 to 135 minutes. They were held from July 2018 to January 2019, in a location previously established by the participant. In order to guarantee anonymity, employees were identified by the letter $C$ followed by a cardinal number according to the order of the interviews (C1 ... C11).

For the selection of employees, the nominal list of employees at that time was used. Participants who entered the Municipal STD/AIDS Program and TCC after the time frame of this research were excluded from the study.

The indirect sources were constituted by scientific articles and books on the theme.

\section{Data analysis}

For the analysis of the documentary corpus, the written sources were catalogued in chronological sequence, and later external and internal criticism was carried out in order to guarantee the authenticity, legitimacy, veracity and reliability of the documents ${ }^{(12)}$. As for the direct oral sources, the interviews were transcribed and validated by the collaborators ${ }^{(13)}$. Since then, the documentary corpus has been subjected to active procedures for interrogating the documents, with an independent posture from the official version, enabling the historical phenomenon to be better evidenced. The reliability of the results was ensured with the valuation of the documentary set and not of the documents in isolation, the following categories emerging: The process of selection and training of the team's professionals; and Place for operation of the Testing and Counselling Center.

\section{RESULTS}

In order to guarantee a service to the population of Nova Iguaçu regarding the need for HIV/AIDS prevention and diagnosis, the Municipal Secretary of Health, at the time, decided to create the Municipal Management Unit of the STD/AIDS Program (UGMPN/ STD/AIDS), which was linked to the Department of Collective Health of the Municipal Health Secretariat. This UGMPN/STD/AIDS would be responsible for actions to fight the epidemic, such as the implantation of the Testing and Counselling Center in that municipality.

To carry out this project, a nurse was appointed to the position of technical manager of UGM PN/STD/AIDS, who, in addition to updating his knowledge about the disease, through participation in scientific events organized by the National STD/AIDS Program, also prepared the "Nova Iguaçu's COAS/TCC Creation Project" in accordance with the Organization and Functioning Norms of the Serological Guidance and Support Center (NOFCOAS) of the National STD/AIDS Control Program. It is worth mentioning that the nurse, a technical manager, had experience in health promotion actions and the implementation of health policies in that municipality, as director of the Department of Public Health. This condition allowed him to accumulate sufficient knowledge about health in the region and in the municipality, which accredited him for the development of public policies, in addition to the social prestige for the occupation of office.

[...] the director of the service [Department] Collective Health of Nova Iguaçu was a nurse. He was responsible for the AIDS Program [technical manager of UGMPN/STD/AIDS] [...]. (C3)

[...] so the nurse who was the head [director] of Collective Health [Department] [...] knew a lot about the health problems in the region and the municipality. (C11)

Thus, the Nova Iguaçu COAS/TCC Creation Project systematized the organization and functioning of this Center - for example, it showed the need for a multidisciplinary team trained to serve users and a suitable location for their installation.

\section{Selection process and training of the team's professionals}

In this sense, the manager of UGM PN/STD/AIDS used the dissemination strategy on the creation of the TCC and attracting professionals to work extensively in the different health units in the municipality and in the Human Resources sector of the Municipal Health Department, according to the speech of a collaborator.

[...] the staffing of the TCC/NI staff took place on a voluntary basis and had as a strategy to attract professionals a wide dissemination in the health units of [municipality] Nova Iguaçu [...]. (C2)

However, we can see that composing the team of professionals for the TCC was a challenge, according to a fragment of a participant's interview.

[...] at the beginning we had some difficulties in composing the team [because] many were afraid of AIDS, because there was not much information about the disease and its contagion, but little by little people came to us to work [...]. (C1) 
It is worth mentioning that all members of the multidisciplinary team were made up of civil servants, with employment contracts at the state and municipal levels, and who were voluntarily assigned to this Center. According to the testimonies of the participants regarding the capacity at TCC:

[...] / had passed the contest in the city [Municipality of Nova Iguaçu] and when I went to introduce myself, they [the SMS through the NI Department of Public Health] were setting up the TCC, so they asked me if I had the courage to work with a HIV patient. I said yes! Then, they sent me to the PAM [Medical assistance station] Dom Valmor [space where the Department of Collective Health worked], where the TCC was being set up [...]. (C9)

[...] I took a contest for the State [State Department of Health of Rio de Janeiro], in the early 1990s, for a special program called PESB, [Special Health Program of Baixada]. Then there was a change for PESB employees and we were going to be moved to other regions of the state. So, he invited anyone who wanted to stay in the municipality of NI, to work at the TCC that was being set up, and so I went [...]. (C6)

To guarantee a quality service in these Centers, there was a concern to establish a minimum team for the operation, consisting of different professionals - among them, doctor, nurse, psychologist, social worker, receptionist and blood collector. As for the constitution of the multidisciplinary team selected to work at TCC/NI, at the time of its creation, this is explained in the excerpt of the interview below:

[...] at that time, there were two nurses on the team, one was the coordinator [technical manager] of the Program [Municipal STD/AIDS Management Unit], counsellors, two doctors, three psychologists, three social workers; at reception, two; and in the lab, two lab technicians[...]. (C10)

In addition to the number of professionals on the multidisciplinary team, it should be properly trained and qualified to serve the users of the Center. In this sense, the technical manager of the UGM PN/STD/Aids was provided with a plan and actions for the training of the team, aiming to establish the new skills and duties of the professionals. It is worth noting that such investment was possible due to the availability of time, about a year, between the selection and constitution of the team and the operation of the TCC.

For this, the nurse used some strategies such as conducting a study conducted at the Department of Public Health in the city. Initially, the professionals were paid for the training received, hours of study, mandatory presence, as shown in the following interview fragment.

[...] we were at the disposal of the SMS [Nova Iguaçu Department of Collective Health], so much that we did not start working soon, he [technical manager of the Municipal STD/AIDS Program] held us at SMS with activities of study, reading texts until opening the TCC [...]. (C4)

[...] so for a year, I think that was almost what we stayed in the secretariat [Department of Collective Health of NI] at the disposal of TCC, which still didn't work. During this period, we had training given by the Program coordinator and the TCC coordinator, articulated with the SES [State Department of Health] [...] these training and studies went on until the TCC's inauguration [...]. (C5)

Other strategies were used by the technical manager of UGM PNSTD/AIDS, such as referring members of the professional team to participate in training and training conducted at the State Health Secretariat of Rio de Janeiro.

[...] we did training in Rio [Rio de Janeiro], we were trained first. We did training at the Health Department [State Health Department] and there we attended lectures, received material for reading. We went through great training. Very good! [...]. (C2)

Aside from these actions, it also encouraged the team to participate in theoretical and practical training at the TCCs of the Hospital Escola São Francisco de Assis, at the Federal University of Rio de Janeiro, and at the Hospital Municipal Rocha Maia, of the Municipal Health Department of Rio de Janeiro.

[...] before we had training, meetings in Rio [Rio de Janeiro], at Hospital São Francisco [Hospital Escola São Francisco de Assis], at TCC, and also at Botafogo [Hospital Municipal Rocha Maia] about counselling [...]. (C5)

\section{Testing and Counselling Center location}

When choosing the Center's operating location, the technical manager of UGM STD/AIDS observed some principles established by the Organization and Functioning Norms of the Serological Guidance and Support Centers, such as the installation of the Center on the premises of an existing health unit and accessibility to users. However, the definition of the location for the operation raised a certain difficulty, with some conflicts between the leaders of the Health Units of the municipality and the manager of the UGM STD/AIDS.

[...] the problem is that when we [manager of the STD/AIDS UGM and TCC coordinator] met, no one [the directors of the Health Units, Primary Care] wanted to give up that place to work with AIDS [...]. (C1)

[...] nobody accepted us, nobody wanted to have a TCC with people with HIV/AIDS in their space that circulated there, nobody wanted. So, to find a place where I could set up a TCC inside [...] it was a difficulty because nobody [the directors of Health Units, Primary Care], nobody accepted [...]. (C2)

After some confrontations, it was established that the TCC would work in the physical blueprint of the Medical Service Post, located in the central region of the municipality. This location, close to the train station and the Nova Iguaçu bus station, guaranteed easy access for users who came in search of service.

[...] worked at the PAM [Medical Service Post] of [Rua] Marechal Floriano, in the center of Nova Iguaçu [...]. (C5)

[...] it was implanted in the PAM [Medical Service Post] of [Rua] Marechal Floriano, the space destined to TCC, it was close to the [railway] station and the Nova Iguaçu bus station [...]. (C7) 
Having defined the location and human resources, the Nova Iguaçu Test and Counseling Center was opened in July 1995. This fact was highlighted in the "Jornal de Hoje", which circulates in the cities of Baixada Fluminense. The article was entitled "TCC can reduce the spread of the AIDS virus in Baixada". The news highlighted the place of operation, the purpose, the constitution of the team and the service flow. The text also pointed out that TCC/NI was the third in the state of Rio de Janeiro and the first in Baixada Fluminense, according to the Municipal Secretary of Health of Nova Iguaçu.

As for the service flow, the article showed that the line of work was established by phase. At first, with the participation in a group to discuss the forms of HIV contamination. In the second phase, the individual meeting to assess the user's conduct regarding exposure to the virus; and, if necessary, they would be sent to the laboratory for blood collection for examination.

This aspect can be observed in the interview section of the employee who worked at that time.

[...] it was very good, [users] arrived and were soon seen at the reception, then [forwarded] to the auditorium [collective pre-test advice], from there to the individual interview service [individual pre-test advice] and to the laboratory [...]. (C5)

As for the physical area of the place for the operation of TCC/ $\mathrm{NI}$, it also met the standards established by the National STD/AIDS Control Program, which provided for a space that combined a welcoming reception, rooms for individual and collective counselling, as well as laboratory. Such fact can be observed in the interview of the participant.

[...] it operated on the third floor, it had the reception, the counsellors' room [individual counselling], a room for collective counselling and the laboratory [...]. (C10)

\section{DISCUSSION}

In order to meet the new health needs of the population, related to the HIV/AIDS epidemic, in view of the high mortality rates in the municipality of Nova Iguaçu, wide dissemination of information on preventive measures and early diagnosis would be necessary, with the creation of a HIV/AIDS Testing and Counselling Center in the municipality, in accordance with the National STD/ AIDS Control Program, of the Ministry of Health.

For this, there was a need for some actions by the municipality authorities, such as the creation of the Municipal STD/AIDS Management Unit, responsible for fighting the disease in Nova Iguaçu, including the creation of a TCC, in order to provide adequate and quality assistance for users. In order to achieve this, a nurse was appointed as a technical manager, who planned actions to create this Center.

The nurse manager of UGMSTD/AIDS has undertaken different strategies throughout the process of creating the TCC. Initially, it sought to update itself on infection and disease, participating in different scientific events, organized by professionals and researchers recognized in the health field. Such investment led to the accumulation of an important volume of scientific and social capital, reflected in his professional qualification to lead the movement to create a device of such scope, as was the TCC at the time. Then, he elaborated a Project for the Creation of the COAS/TCC of Nova Iguaçu, in accordance with the NOFCOAS determinations of the National STD/AIDS Control Program.

Therefore, the scientific capital accumulated in and by the field gave the nurse manager the status of spokesperson for a legitimate speech on the creation of the TCC, both by the recognition of peers and by the occupation of the position. Therefore, the nursing manager's capital portfolio determined his position in the field. This is because the value of any form of capital depends, in part, on its social recognition ${ }^{(14)}$.

Regarding the selection of human resources, although using wide dissemination, there were difficulties in composing the health team to work in the TCC, that is, in the prevention and diagnosis of HIV/AIDS. It is worth mentioning that, at that time, the disease represented a threat, both for the patient and their family members and for the health professionals, due to the little information, the fact that it is a disease without cure and that led to death ${ }^{(10,15)}$. All of this generated stigma, especially if associated with religious principles, because, in these cases, there is still the feeling of guilt ratified under the discourse of sin/punishment. Despite the difficulties reported by employees, the team was made up of professionals, with public servants, who worked in different health units in Nova Iguaçu and who, for different reasons, sought the service by applying or being invited to compose the team, who would work at TCC. Thus, the team met the norms of the National STD/AIDS Control Program, both in terms of the number of professionals and the diversity of academic backgrounds.

As for the training of the health team, there was a large investment; the nurse responsible for the creation of the TCC/NI considered the qualification of the team on the subject to be important and, thus, maintained the qualification and training, from the composition of the team to the implantation of the Center. It is worth noting that the fact that the coordinator of the STD/AIDS Program of the municipality of Nova Iguaçu kept a team of professionals, for approximately one year, outside the health units of that municipality, available for qualification and training, gave him the power and prestige, granted by city authorities, such as the Mayor and the Secretary of Health.

Regarding the relevance of the training and qualification of the multidisciplinary team, in a study carried out on training and practice in the Testing and Counselling Centers, the authors point to the importance of developing skills in training, in addition to the constant updating of knowledge through education. continued in service, establishing adjustments in the routine of each Center ${ }^{(16)}$.

It should be noted that the personal development of competences, skills and attitudes, through in-service training, gained prominence in the context of health from the 1990s. With the reform in the sector and the construction of a new model of health care in Brazil, the Unified Health System highlighted the need for the qualification of professionals, in order to offer quality care to users and, thus, add values to professionals and to health units ${ }^{(17)}$.

It is worth noting that training should be understood as an educational strategy to enable people to carry out activities in the service, with the purpose of both personal and professional development and, therefore, contribute to the improvement of 
skills, such as: manual dexterity for the carrying out practical-manual work; the mental capacity through the domain of knowledge to perform the task; in addition to the development of judgment capacity, which favors decision-making in the face of problem situations in daily professional practice ${ }^{(17-18)}$.

Regarding the location, training can be internal or external. Internal training is when it takes place inside the workplace; and the external, when performed outside the service location. In general, external training takes place in consulting companies specialized in training, reference centers and by renowned specialists in a given subject ${ }^{(18)}$.

Regarding the investment given to the training and qualification of the multidisciplinary team, it can be observed that the training took place in the form of both internal and external training. Regarding internal training, these took place providing hours of study, with mandatory presence, carried out on the premises of the Department of Collective Health of the municipality. The external training that took place at the STD/AIDS Advisory Office of the Rio de Janeiro State Health Secretariat (SES/RJ) was carried out through thematic meetings with renowned professionals, who held a large volume of scientific capital and held prominent positions in the field of infectious diseases in the state of Rio de Janeiro and Brazil; thus, they functioned as authorized spokespersons in the field of infectious diseases and the HIV/ AIDS epidemic in the state and in the country.

Still on the external training carried out at the TCCs of the Hospital Escola São Francisco, of the Federal University of Rio de Janeiro, and at the Hospital Municipal Rocha Maia, of the Municipal Health Secretariat of Rio de Janeiro, it is worth noting that the two became Training Centers for the training of professionals since 1993, with the responsibility of qualifying professionals for the creation of new TCCs in Rio de Janeiro and other states in Brazil(19-20).

Another challenge to be overcome by the nurse manager of UGM/STD/AIDS in the process of creating the Nova Iguaçu TCC was the difficulty in finding a working place for the Center. This situation can be characterized by the resistance of some directors of health units to give space to these facilities. Even though it is a project of such a large scale, aligned to the health context, besides being endorsed by the greatest local authority, the mayor, there was still resistance to the creation and implementation of the Center. Such a situation may have occurred due to the managers' understanding that this would expose the units they ran and the health professionals who worked in it, when caring for users who needed specialized care for a TCC.

In this sense, a study stands out that registers a great challenge to define a place for the implantation of these Centers, in order to guarantee the access of users with ease of public transport ${ }^{(21)}$. Thus, the difficulty in establishing the place of operation of the TCC may be related to the type of user of the Center, that is, people who were in a situation considered to be at risk for HIV/ AIDS infection. That's because, at the time, AIDS was a disease restricted to men who have sex with men, injecting drug users and sex workers, that is, present in groups of people considered to be on the margins of society ${ }^{(22)}$.

Thus, the choice of the Medical Service Post as the place of operation of the TCC combined the ease of access of people from different neighborhoods and municipalities in the state of
Rio de Janeiro, who needed this service, with some privacy in their location, to contribute to mitigate the risk of users meeting people such as friends and family.

The relevance in choosing the location of these Centers is based on the need to ensure discretion, since most users preferred to seek care at the TCC away from their residence or neighborhood, due to the fear of being seen by acquaintances, neighbors and family members. Thus, this demonstrated that, in addition to ease of access, the location's discretion directly interfered in the users' search for these Centers ${ }^{(23-24)}$.

In addition, the structure of the Medical Service Post, which could be used to locate the TCC/NI, had a large and adequate physical space, meeting the needs for the proper functioning of this Center. This is because, according to the TCC/NI creation project, the physical area should be large and allow satisfactory service to users, in addition to having a reception room; collective counselling room, with capacity for approximately 20 people; rooms for individual counselling; and space for the laboratory.

The use of the Medical Service Post as a space for the functioning of the TCC led to conflicts between the director of the Medical Service Post and the manager of the Municipal STD/AIDS Management Unit, the latter being responsible for implementing a device of the National Control Program of STD/AIDS, from the Ministry of Health, considered relevant at the time for the control of the epidemic. Despite the fact that both occupied positions of power, the professional capital of the manager of the UGM PN STD/AIDS was more efficient, since the final decision favorable to the installation of the space TCC was prevailed.

It is worth mentioning that the implantation of the Testing and Counselling Center, at the national level, was a strategy of the Ministry of Health, given the fight against the epidemic that was plaguing Brazil at that time. In this context, information on the number of people living with the virus and on the interruption of transmission mechanisms would be relevant. For that, the way of knowing the HIV serological condition in the population was universal testing. Therefore, in order to minimize the risks of HIV/AIDS infection, it was important to implement counselling actions for users of these Centers ${ }^{(25)}$.

In order to guarantee the attendance of a significant number of people and minimize the effects of the epidemic on the population, it would be necessary to encourage the demand for these Centers. So, in this context, organizational operating principles were established, based on universal access to diagnosis, through voluntary assistance, guaranteeing the anonymity and confidentiality of user information. In addition, the studies pointed out the need to establish a link between the professional and the user. It should be added that the aspects most highlighted by users regarding this relationship were confidentiality and anonymity ${ }^{(26-28)}$.

Thus, the Testing and Counselling Centers presented themselves as a social space at the secondary level of health care, focused on specialized care in HIV/AIDS, contributing significantly to the control of the epidemic in the country. They carried out diagnostic actions and preventive measures, guaranteeing accessibility, universal and quality care, based on ethical precepts, commitment and responsibility with the users of these Centers ${ }^{(28)}$.

Such measures involving the Testing and Counselling Centers gain more relevance as we know that the Southeast Region of 
Brazil is the one with the highest number of AIDS cases, with about 170 thousand notifications, $67 \%$ of the total cases in the period of 1982 to 2001, part of the time frame of this research. With regard to the state of Rio de Janeiro, in the period from 1982 to 2001, around 35 thousand cases of AIDS were reported, $90 \%$ of which were concentrated in the Metropolitan Region; and among the ten municipalities that had the highest number of cases, Nova Iguaçu ranked second, with 2,070 notifications, corresponding to $5.8 \%$ of the total notifications ${ }^{(7)}$.

According to a study by the Institute of Research and Urban and Regional Planning of the Federal University of Rio de Janeiro (IPPUR/UFRJ) among the municipalities of the state of Rio de Janeiro, Nova Iguaçu revealed the highest AIDS rates, in terms of both incidence of this disease as of mortality, with 20.9 deaths per 100 thousand inhabitants, surpassing the Brazilian and Southeast Region average, considered the region with the worst indicators for the disease ${ }^{(8)}$.

\section{Study limitations}

As for the limitations of the study, they are related to the possibility of locating other historical sources. Despite the search for an expanded and judicious way of the documents, such expansion in future studies would culminate in adjustments in this historical narrative.

\section{Contribution to the area}

The study may contribute to the understanding about the planning and organization of a TCC and its impact in preventing HIV/AIDS infection. In the context of health, it highlights the strategies of health professionals, especially nurses, in the fight against the epidemic in Brazil and Nova Iguaçu, through the incorporation of knowledge about the health demands of the population and public policies, with the aim of result in the creation of a Testing and Counselling Center. Thus, this work also contributes to the professional training process, since it shows the importance of management in the service and in care, in addition to assisting in the development of human sensitivity, so characteristic of nursing care.

Furthermore, it constitutes an analytical tool for other research by health professionals, as it emphasizes planning, challenges and the creation of a specialized service with great social impact.

\section{FINAL CONSIDERATIONS}

After the creation of the Municipal STD/AIDS Management Unit, responsible for the implementation of actions to fight the epidemic, and the appointment of a nurse as a technical manager, the planning and operationalization for the creation of this Center began.

Challenges arose both for the choice of the place of operation and for the constitution of the team that would work at the TCC, possibly due to the type of clientele to be served, people with HIV/ AIDS, that is, it was a disease little known in the health field, without cure, characterized by high mortality rates and stigmatized, which disqualified the social identity of its carriers. Still, it is highlighted that, for the training of the team, the nurse used innovative or appropriate strategies aiming at the competences and skills for an efficient and quality care. Such strategies provided the updating of the scientific and professional capital of the team, evidenced by the incorporation of new knowledge, meeting the requirements established in the Organization and Functioning Norms of the Serological Guidance and Support Centers, of the Ministry of Health.

It is worth noting that the investment of the technical manager of UGM/STD/AIDS culminated in the beginning of TCC/NI activities, in July 1995. For the Center to become a specialized space and a regional reference, in the face of the challenges of the HIV/ AIDS epidemic, it was necessary to have an adequate location for the facilities and a team of qualified professionals. The effort and authority of the technical manager nurse of UGM /STD/AIDS contributed to the consolidation of a space with possibilities for the development of a quality care practice for users, with regard to preventive measures and the early diagnosis of HIV/AIDS in Nova Iguaçu, a city with very unfavorable epidemiological indicators related to HIV/AIDS, considering the time frame of this research.

\section{REFERENCES}

1. Oliveira FBM, Queiroz AAFLN, Sousa AFL, Moura MEB, Reis RK. Sexual orientation and quality of life of people living with HIV/ AIDS. Rev Bras Enferm. 2017;70(5):1004-10. doi: 10.1590/0034-7167-2016-0420

2. Pinto ACS, Pinheiro PNC, Vieira NFC, Alves MD. Compreensão da pandemia da AIDS nos últimos 25 anos. DST J Bras Doenças Sex Transm [Internet]. 2007 [cited 2020 Jun 4];19(1):45-50. Available from: http://www.dst.uff.br/revista19-1-2007/7.pdf

3. Nascimento DR. As Pestes do Século XX. Tuberculose e AIDS no Brasil, uma História Comparada. Rio de Janeiro: Ed. FIOCRUZ, 2005.

4. Reis AC, Santos EM, Cruz MM. A mortalidade por AIDS no Brasil: um estudo exploratório de sua evolução temporal. Epidemiol Serv Saúde. 2007;16(3):195-205. doi: 10.5123/S1679-49742007000300006

5. Ministério da Saúde (BR), Secretaria de Vigilância de Saúde, Programa Nacional de DST e AIDS. A Comissão Nacional de AIDS: Secretaria de Vigilância em Saúde, Programa Nacional de DST e AIDS. Brasília (DF): Ministério da Saúde; 2001.

6. Bastos FI. Da persistência das metáforas: estigma e discriminação e HIV/AIDS. In: Monteiro S, Villela W (Org.). Estigma e Saúde. Rio de Janeiro: FIOCRUZ; 2013. 207 p.

7. Souto MC. Projeto AIDS II e a Implementação das Ações de Prevenção do HIV/ AIDS no Estado do Rio de Janeiro [Dissertação] [Internet]. Rio de Janeiro; Escola Nacional de Saúde Pública (ENSP/FIOCRUZ). 2003 [cited 2020 Jun 4]. Available from: https://www.arca.fiocruz.br/handle/icict/5470 
8. Universidade Federal do Rio de Janeiro. Instituto de Pesquisa e Planejamento Urbano e Regional da Universidade Federal do Rio de Janeiro (IPPUR/UFRJ). Projeto Localização dos Objetivos do Milênio. Cidade de Nova Iguaçu. Rio de Janeiro: UFRJ; 2006.

9. Ministério da Saúde (BR), Secretaria de Assistência à Saúde, Coordenação Geral do Programa Nacional de Controle de Doenças Sexualmente Transmissíveis/AIDS. Normas de Organização e Funcionamento dos Centros de Apoio Sorológico. Brasília (DF): Ministério da Saúde, 1993.15 p.

10. Laurindo-Teodorescu L, Teixeira PR. Histórias da AIDS no Brasil: as respostas governamentais à epidemia de AIDS. Ministério da Saúde/ Secretaria de Vigilância em Saúde/Departamento de DST, AIDS e Hepatites Virais. v.1. Brasília: 2015. 466 p.

11. Instituto Brasileiro de Geografia e Estatística. Índice de Desenvolvimento Humano. 2010. Available from: https://censo2010.ibge.gov.br/ resultados.html

12. Padilha MICS, Borenstein MS. The methodology of historic research in the nursing el método de investigación histórica en la enfermería. Texto Contexto Enferm. 2005;14(4):575-84. doi: 10.1590/S0104-07072005000400015

13. Meihy JCSB, Ribeiro SLS. Guia prático de História Oral. São Paulo: Contexto;2011. 208p.

14. Grenfell M. Pierre Bourdieu: conceitos fundamentais. Petrópolis: Vozes; 2018.400 p.

15. Neves LCR, Amorim WM, Moraes NA, Leite JL. Os cuidados de enfermagem ao cliente com HIV/ AIDS em um Hospital Universitário na Década de 1980. Rev Pesqui: Cuid Fundam. 2009;1(2):299-316. doi: 10.9789/2175-5361.rpcfo.v13.7159

16. Mora C, Monteiro S, Moreira COF. Formação, práticas e trajetórias de aconselhadores de centros de testagem anti-HIV do Rio de Janeiro, Brasil. Interface. 2015;19(55):1145-56. doi: 10.1590/1807-57622014.0609

17. Ranzini MS, Bryan NAP. Capacitação e formação para o setor público e os modelos de escola de governo no Brasil. Rev Serv Público. 2017;68(2):417-438. doi: 10.21874/rsp.v68i2.1004

18. Bagattoli SL, Müller GCK. Treinamento e desenvolvimento de pessoal: agregando valor às pessoas e à Organização. NAVUS, Rev Gestão Tecnol. 2016;6(2):106-20. doi: 10.22279/navus.2016.v6n2.p106-120.337

19. Ministério da Saúde (BR), Secretaria de Vigilância em Saúde Programa Nacional de DST e AIDS. Centro de Testagem e Aconselhamento (CTA): integrando prevenção e assistência. Brasília (DF): Ministério da Saúde, 2005.

20. Ferreira MPS. O CTA São Francisco: um olhar a partir da assessoria de DST/ AIDS da SES - RJ. In Ministério da Saúde (BR). Secretaria de Vigilância em Saúde Programa Nacional de DST e AIDS. Centro de Testagem e Aconselhamento (CTA): integrando prevenção e assistência. 2004. p. 43-55.

21. Minayo MCS, Souza ER, Assis SG, Neto OC, Delandes SF, Silva CMFP. Avaliação dos Centros de Orientação e Apoio Sorológico/CTA/Coas da Região Nordeste do Brasil. Cad Saúde Pública. 1999;15(2):355-36. doi: 10.1590/S0102-311X1999000200020

22. Caliari JS, Teles SA, Reis RK, Gir E. Factors related to the perceived stigmatization of people living with HIV. Rev Esc Enferm USP. 2017;51:e03248. doi: 10.1590/S1980-220X2016046703248

23. Zambenedetti G, Both NS. "A via que facilita é a mesma que dificulta”: estigma e atenção em HIV- AIDS na Estratégia Saúde da Família-ESF. Fractal, Rev Psicol[Internet]. 2013[cited 2020 Jun 4];25(1):41-58. Available from: https://periodicos.uff.br/fractal/article/view/4928

24. Campillay MC, Monardez MM. Estigma y discriminación en personas con VIH/SIDA, un desafío ético para los profesionales sanitarios. Rev Bio y Der [Internet] 2019 [cited 2020 Jun 4];47: 93-107. Available from: http://scielo.isciii.es/pdf/bioetica/n47/1886-5887-bioetica-47-00093.pdf

25. Magnabosco GT, Lopes LM, Andrade RLP, Brunello MEF, Monroe AA, Villa TCS. Assistência ao HIV/aids: análise da integração de ações e serviços de saúde. Esc Anna Nery. 2018;22(4):e20180015. doi:10.1590/2177-9465-ean-2018-0015

26. Leadebal ODCP, Medeiros LB, Nascimento JA, Monroe AA, Nogueira JA. Classification of clinical risk in people with AIDS followed up in specialized care. Rev Bras Enferm. 2018;71(5):1235-42. doi: 10.1590/0034-7167-2017-055

27. Silva RAR, Costa RHS, Braz LCSB, Lucena IA, Ferreira KSF, Duarte FHS. People living with AIDS: Association between nursing diagnoses and sociodemographic/clinical characteristics. Rev Bras Enferm [Internet]. 2018;71(5):2535-42. doi:10.1590/0034-7167-2017-0420

28. Rocha KB, Ew RAS, Moro LM, Zanardo GLP, Pizzinato A. Aconselhamento na perspectiva de profissionais da atenção básica. Cienc Psicol. 2018;12 (1):67-78. doi:10.22235/cp.v12i1.1597 